\title{
Optimal government size and economic growth in Spain. Evidences through the Armey Curve (1980-2016).
}

\author{
Carlos Navarro García, PdH. \\ Universidad Alfonso X. Madrid (Spain)
}

\begin{abstract}
This study analyzes the effect of public expenditure on economic growth for the Spanish economy, in the period between 1980 and 2016. The Armey curve is used as an analytical tool to describe the relationship between the two variables indicated. The two objectives of this study are check if there is a quadratic relationship of this kind between the two variables for the Spanish economy, as predicted by the model, and there, calculate their optimum. The empirical findings indicate the existence of a significant relationship inverted $U$-shaped between the two variables in the Spanish economy, obtaining an optimal public expenditure in Spain of $40.07 \%$ of GDP, $5.07 \%$ lower than the size of the public sector by 2016. Based on these results, an economic policy proposal could be the need to reduce the percentage of public expenditure with the goal of attaining greater efficiency in the Spanish economy.
\end{abstract}

Key words: Armey Curve, economic growth, public expenditure, government size JEL classification: C22; E62; H11; H50

\section{INTRODUCTION}

The relationship between economic growth and the size of the public sector has traditionally been the subject of special attention from economists. The issue has a particular interest due to the increased weight of the public sector overall economy of recent decades in developed economies, something that has been accompanied by an increase in public debt as well as the existence of persistent public deficits. All it link to a growth of public expenditure more than expected in the medium-term and long-term because, among others, factors such as the rapid aging of populations in developed nations and strain on pensions, has led to focus for different researchers of economic growth in the size of the public sector and its effect on the economy.

In Spain, the total public expenditure ${ }^{1}$ in 2016 reached $42.2 \%$ of GDP (reaching the highest point of $48.1 \%$ in 2012 , with $31.16 \%$ in 1980 ), which has been accompanied by a growing increase in both public debt (99\% of GDP by 2016, with $16.58 \%$ in 1980) and the existence of a persistent deficit (-4.51\% in 2016). In OECD countries, average public expenditure accounted for about 41\% of GDP by 2016.

In this context, as noted, there is a growing debate about the effect of public expenditure on economic growth. There is usually consensus to accept a certain level of public expenditure is essential to maintaining the basic characteristics of the state, such as security, stability, or the state administration; however, there are doubts about the negative effect of public expenditure on economic growth from a certain point.

1It includes state, regional and local public spending. SOURCE: INE 
There are two main approaches in economic theory to economic growth and its determinants. The first and oldest is found in the neoclassical model of Solow (1955) and Swan (1956), where the level of production is determined by two exogenous variables: physical capital and labor. For this model, since growth is given by exogenous factors, the effect of government expenditure on economic growth has no effect on the same except some influence on the transition to steady state (stationary situation to which the economies send when the output per capita is constant), which in any case it depends on technological progress. That is why this model does not study the effect of the public sector.

New economic growth theories, from the work of Romer (1986), Lucas (1988) and Clay (1989; 1990), suggest that both the steady state and the transition state are endogenous, and there are different determinants the long-term economic growth. Thus, there may be different rates of economic growth in the long-term in different economies without the convergence predicted by the neoclassical model countries occur finish. In this context, the effect on the growth of the state has a recognizable effect, through three main instruments: government expenditure, taxes and deficit.

From this last approach, the relationship between economic growth and size of the public sector, as well as the calculation of the optimum point of that relationship, it is an aspect that has aroused some interest in recent decades, after the appearance of the Armey Curve theory, also called Rahn curve or BARS curve, referring to Clay (1989), Armey (1995), Rahn (1996) and Scully (1998).

Armey curve collects existing non-linear relationship between the size of a government, measured by public expenditure and economic growth through the formation of a curve with an inverted U shape between the two variables.

Said curve, as Faccini and Melki (2011) indicate, combines two differentiable parts of the effect of public expenditure on economic growth: on the one hand a positive influence and on the other hand in which, from a certain point curve, public expenditure has no longer a positive effect on economic growth. The curve maximum signal the optimal size of government (b in Figure 1), measured on public expenditure, in the sense that maximize the same at that point.

Figure 1. Armey curve.

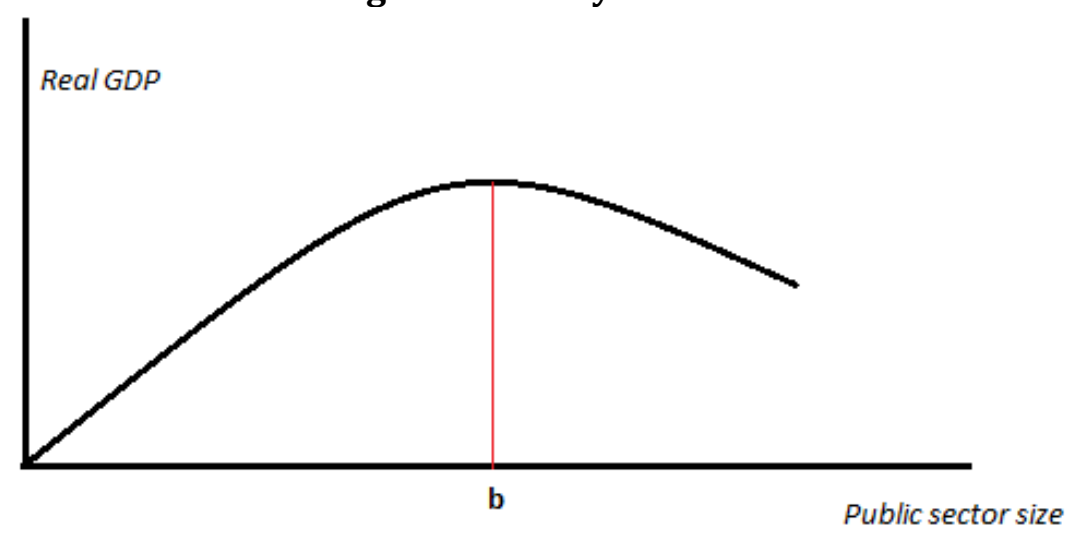

Conceptually, and following the authors cited, the curve finds its justification on the existence of two features of public expenditure: on the one hand, its positive influence to correct market failures, on the other hand its negative influence with the emergence of failures of state, so that the curve reflects both aspects of public expenditure. 
The Armey curve model has been studied empirically in recent years through different methodologies, both time series as panel data. Although there are several mathematical model approaches, the most widely used is the one that the quadratic function for its empirical development is used. The basic model is as follows:

$\mathrm{y}_{\mathrm{it}}=\alpha+\beta_{1} \mathrm{EXP}_{\mathrm{it}}+\beta_{2} \mathrm{EXP}^{2}{ }_{\mathrm{it}}+\mu \mathrm{U}_{\mathrm{it}}+\mathrm{e}_{\mathrm{it}}$

With $\mathrm{i}=1 \ldots N$ and $\mathrm{t}=1 \ldots . \mathrm{T}$

Where $y$ is the economic growth, EXP is public expenditure, $U$ is a vector that includes various control variables that affect the growth, and $e$ is the error term.

The model contains both linear and nonlinear part of the relationship between the two factors. Thus, the existence of the Armey curve is confirmed by obtaining a positive sign in the coefficient $\beta_{1}$, and a negative sign on the coefficient $\beta_{2}$ after applying econometric analysis, fulfilling therefore predicted by the model.

In order to calculate the optimal public expenditure which maximizes economic growth, the following equation is used:

Optimal spending $=\frac{-\beta_{1}}{2\left(\beta_{2}\right)}$

This equation represents the point of the curve which optimizes public expenditure.

Through this study, the effect of the size of the public sector (measured as a percentage of public expenditure on GDP) on economic growth in the Spanish economy over a period of 37 years (1980-2016) is analyzed, which correspond almost all the years since the advent of democracy, through the Armey curve model, and calculating the optimal size of the state for the Spanish economy. The objectives of the study are (a) check if a significant relationship exists, in the form of "inverted U" between both variables, as predicted by the model curve Armey, and if any, (b) calculate the optimal size of government for the Spanish economy.

\section{LITERATURE REVIEW}

Empirical studies designed to verify the existence of the Armey curve in different economies are relatively recent, and most of them carried out through the Armey model reveal the existence of a quadratic relationship in an inverted $U$ shape between the two variables study also offering different optimal sizes of the public sector, depending on the sample collection years, the level of development of the economy analyzed, and the control variables used.

Using analysis of time series, as the present study does, Vedder and Gallagay (1997), one of the first empirical Armey model approximations, find their existence in the analysis of different periods (in parentheses) US (1947 -1997), Canada (1926-1988), Denmark (1854-1988), Italy (1862-1988). Sweden (1881-1988), and the United Kingdom (1830-1988), obtaining an optimum size between $17.5 \%$ (for the US case) and 26.14\% (in the case of Denmark).

Pevcin (2004) finds the relationship indicated by the Armey curve in Italy, France, Finland, Sweden, Germany, Ireland, the Netherlands and Belgium, for a period between 1950 and 1996, with optimal sizes ranging between $37.09 \%$ and $45.96 \%$.

Mavrov (2007), for the period between 1990 and 2004 in Bulgaria, confirmes the model and places the optimal size of the Bulgarian economy by $21.42 \%$. 
Roy (2009), through a multi-equation model and for the period between 1950 and 2007, finds a significant and negative relationship between government size and economic growth in the United States.

Herath (2010) analyzes the relationship between the two variables for the case of Sri Lanka, using polynomial regression of the second degree. Their findings confirm the existence of quadratic relationship according to the idea of Armey.

Forte and Magazzino (2011) find a nonlinear relationship between the two variables studied in the analysis of the economy of Italy in the period between 1861 and 2008.

Facchini and Melki (2011) find the existence of such a relationship for French economy in a period of study comprised between 1871 and 2008.

Faruk and Aydun (2013) find significant relationship for both variables, confirming the validity of the model Armey, analyzing the period between 1995 and 2011 for the economies of Turkey, Romania and Bulgaria, giving an optimal level of public expenditure in relation to GDP of $25.21 \%, 20.44 \%$ and $22.45 \%$ respectively.

\section{EMPIRICAL MODEL}

\section{Data}

For estimation, the model represented by the formula (1) is used. Economic growth data (measured in annual growth rate) and size of the public sector as a percentage of GDP, used in this study, were taken from the database of the OECD. Data on government deficits and the degree of openness of the Spanish economy come from national accounts published by the Spanish government data used for the period between 1980 and 2016, coinciding with the arrival of democracy to Spain and development economic policy through stable governments.

Statistical analyzes were performed with R software, except causality test, that was performed with E-views. In the present model, the dependent variable is the rate of annual economic growth per capita GDP at constant prices of Spain. The independent explanatory variable is the total public expenditure Spanish (GPUBLICO), including all Spanish public administrations (local, regional and national) as percentage of total Spanish GDP. The following control variables are used, which have been shown to be important for the analysis of the model in previous studies: Level of openness (TAPERTURA)² and budget deficit (DEFICITP).

\section{Unit root test}

This study uses time series, so it is necessary to ensure the stationarity of the series of data that make up each of the variables of interest, so that the regression is valid. Stationarity of data is studied through testing unit root (root unit tests): ADF test and PP test. The results are indicated in Table 1.

${ }^{2}$ It consists of the sum of imports and imports divided by GDP. 
Table 1. Tests Unit root. ADF and PP tests

Augmented Dickey-Fuller Test (ADF Test)

\begin{tabular}{lcc}
\hline \multicolumn{1}{c}{ Variable } & Statistic & p-value \\
\hline CRECEC $(-1)$ & $-5,3982$ & 0,01 \\
GPUBLICO (-1) & $-4,0656$ & 0,01838 \\
GPUBLICO $^{2}(-1)$ & $-4,188$ & 0,01377 \\
DEFICITP(-1) & $-4,2763$ & 0,01044 \\
TAPERTURA(-1) & $-6,3183$ & 0,01
\end{tabular}

\begin{tabular}{lcc}
\multicolumn{3}{c}{ Phillips-Perron Test (PP Test) } \\
\hline \multicolumn{1}{c}{ Variable } & Statistic & p-value \\
\hline CRECEC (-1) & $-30,743$ & 0,01 \\
GPUBLICO (-1) & $-25,647$ & 0,01 \\
GPUBLICO $^{2}(-1)$ & $-26,9$ & 0,01 \\
DEFICITP(-1) $_{\text {TAPERTURA(-1) }}$ & $-24,885$ & 0,01 \\
TAR & $-33,754$ & 0,01
\end{tabular}

Both tests indicate that the series of the dependent variable (CRECEC) and independent determinant (GPUBLICO) are stationary series of order 1, and the control variables used too.

\section{Cointegration}

To evaluate the cointegration between dependent variable (CRECEC) and independent variable (GPUBLICO), a linear regression model is adjusted between the variables and we perform the ADF test to the residuals, obtaining a statistic -6.1661 and a $p$ value $<0,01$ indicating that we have two stationary variables of order 1 with linear combination of order 0 , so we can say that the variables are cointegrated.

\section{Causality.}

To analyze causality, in order to confirm the existence of Wagner Law, which considers economic development of a country leads to increased pressures by the population in favor of increased public expenditure, we use the Granger causality test, through preliminary analysis of the variables through the method of Vector Autoregressive (VAR), allowing us to take the appropriate number of lags for testing, and providing thus more power to the test by not backlogs selection made arbitrarily. Causality analysis through Granger test does not provide for both analyzed variables, economic growth and public expenditure, to obtain conclusive not significant p-values in both.Results as shown in Table 2. 
Table 2. Analysis of Granger causality (VAR)

\begin{tabular}{cccc}
\multicolumn{2}{l}{ Dependent variable: CRECEC } \\
\hline \hline excluded & Chi-sq & df & Prob. \\
\hline \hline GPUBLICO & 0.392243 & two & .8219 \\
\hline \hline All & 0.392243 & two & .8219 \\
\hline \hline
\end{tabular}

Dependent Variable: GPUBLICO

\begin{tabular}{cccc}
\hline \hline excluded & Chi-sq & df & Prob. \\
\hline \hline CRECEC & 2.304104 & two & .3160 \\
\hline \hline All & 2.304104 & two & .3160
\end{tabular}

\section{RESULTS}

Since we find stationary study variables of order 1 cointegrated, we proceed to econometric analysis model through OLS regression.

The results obtained (Table 3), through ordinary least squares regression, we show that the coefficients of the analysis variables have the correct signs as predicted by working hypothesis. The two variables relating to public expenditure, GPÚBLICO and (GPUBLICO) ${ }^{2}$, show the expected signs and are statistically significant, which allows us to confirm the existence of a curve inverted U-shaped in the impact of public expenditure on economic growth. Therefore, the results indicate that the existence of Armey curve holds for the Spanish economy in the period under review.

Table 3. Results of the econometric analysis by OLS.

\begin{tabular}{cccccl}
\hline Variable & Coefficient & Standard error & t-value & $\operatorname{Pr}(>|t|)$ & \\
\hline intercept & -0.10043 & 0.19914 & -504 & 0.61761 & \\
GPUBLICO (-1) & 3.32843 & 1.17248 & 2,839 & 0.00792 & $* * *$ \\
SQ-GPUBLICO (-1) & -0.4153 & 0.0138 & -3.009 & 0.00518 & $* * *$ \\
DEFICIT (-1) & 0.37519 & 0.15528 & 2,416 & 0.02177 & $* *$ \\
T open (-1) & 0.13539 & 0.07129 & 1,899 & 0.0669 &. \\
\hline
\end{tabular}

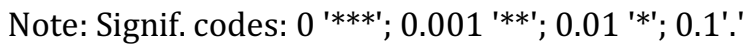

The adjusted coefficient of determination ( $\mathrm{R}^{2}$ adj) model is $57.81 \%$, with a $\mathrm{p}$-value for the overall model 2.528e-6, so this is a statistically significant model. As shown in Table 3, the coefficients of the control variables are also significant statistically in different degrees, both with positive sign.

After confirming the existence of the curve Armey for Spanish to the analyzed period, we can calculate the optimal size of the Spanish state that maximizes economic growth, from the formula (2). The result is $40.07 \%$.

\section{CONCLUSIONS}

Following Armey curve model, I have confirmed the presence of non-linear relationship between economic growth and weight of the public sector in Spain, in the period from 1980 to 2016. The study results confirm the statistically significant nonlinear relationship between the 
two variables, and suggest that the optimal size of government expenditure as a percentage of GDP in Spain stood at 40.07\%, size in line with results obtained by other countries in our environment for the same periods.

When we compare our results with data from 2016, the findings of the work leads us to the current size of the Spanish state, in terms of public expenditure as a percentage of GDP exceeds its optimal size by $5.07 \%$ (reaching overcome a $20.04 \%$ at its highest point, in 2012)

Following economic theory, overcome public expenditure above the optimum level involves loss of efficiency by the public sector, so the Armey curve can be used as a tool of economic policy to determine levels of efficiency in public expenditure an economy.

\section{Bibliographic references}

Armey, D. and Armey, R. (1995) The Freedom Revolution: The New Republican House Majority

Barro, R.J. (1989) A Cross-Country Study of Growth, Saving and Government. NBER Working Paper No. 2855.

Barro, R.J. (1980) Government Expenditure in a Simple Model of Endogenous Growth. Journal of Political Economy, 98, October, part II, S103-2125.

Coll, S. (2014) Is there to much government in Developed Countries? A time-series analysis of 24 OECDeconomies. Journal of Heterodox Economics. Volume 1, Issue 1.

Forte, F. and Magazzino, C. (2011) Government Size and Economic Growth in Italy: A Time-series Analysis. European Scientific Journal vol.12, No.7 ISSN: 1857-7881

Facchini, F. and Melki, M. (2011) Optimal government size and economic growth in France (1871-2008): An explanation by the State and market failures. Id HAL: halshs-00654363, in aviablehttps://halshs.archivesouvertes.fr/halshs-00654363

Farouk, O. and Aydun, C. (2013) The Relationship Between Optimal Size of Government and Economic Growth: Empirical Evidence from Turkey, Romania and Bulgaria. Proceeded - Social and Behavioral Sciences 92, 66-75

Herath, S. (2010) The Size of the Government and Economic Growth: An Empirical Study of Sri Lanka. SRE Discussion Papers, 2010/05. WU Vienna University of Economics and Business, Vienna.

Lucas, R .(1988). On the Mechanics of Economic Development. Journal of Monetary Economics, 22, July, 3-42.

Magazzino, C. and Forte, F. (2010) Optimal size of government and economic growth in EU-27. Munich MPRA Paper No. 26669, online athttp://mpra.ub.uni-muenchen.de/26669/

Mavrov, H. (2007). The Size of Government Expenditure and the Rate of Economic Growth in Bulgaria. Online Access inhttp://alternativi.unwe.acad.bg/bu18/06.pdf

Pevcin, P. (2004) Does optimal size of government expenditure exist? Paper presented to the European Group of Public Administration (EGPA) Annual Conference. Ljubljana, Slovenia, 1-4 September 2004.

Rahn, R. and Fox, H. (1996). What is the Optimum Size of Government. Denver, CO: Vernon K. Krieble Foundation. Romer, P.M. (1986). Increasing Returns and Long-Run Growth. Journal of Political Economy, 94, October, 1002 to 1037.

Roy, A. (2009) Evidence on Economic Growth and Government Size. Applied Economics. 41. 607-614. 10.1080 / 00036840601007393.

Scully, G. (1998) Measuring the Burden of High Taxes, National Center for Policy Analysis Policy Report No. 215 Solow, R.M. (1956) A Contribution to the Theory of Economic Growth. Quarterly Journal of Economics. 70 (1), 6594.

Swan, T.W. (1956) Economic Growth and Capital Accumulation. Economic Record, 32 (2), 334-361.

Vedder, R.K. and Gallaway, L.E. (1998) Government size and economic growth. Prepared for the Joinf Economic Committee. Washington, DC: Joint Economic Committee. 